\title{
After-Death Manipulation: The Treatment of the Skull in Prehistoric Funeral Contexts
}

\author{
Alessia Zielo* \\ Department of Philosophy, University of Padua, Italy
}

Submission: July 11, 2018; Published: August 22, 2018

*Corresponding author: Alessia Zielo, Department of Philosophy, Sociology, Pedagogy and Applied Psychology (FISPPA) - University of Padua, Italy, Email: alessia.zielo@gmail.com

\begin{abstract}
The preservation of the skull (or a part of it) of the dead is linked to the cult of the ancestors and with the idea that the spirit dwells in preference in the head of the deceased. The practice of the selection and conservation of human skulls is found quite regularly starting from the last phase of the Upper Paleolithic, the Maddalenian, and then developed during the European Mesolithic period (X-VII Millennium). The archaeological evidence analyzed up to now: the ritual treatment of the skull, together with the care in the disposal of the bodies, the presence of tools, food and non-instrumental objects such as flowers or animal horns, the application of agents such as red ocher and the shells, shows the attention given to the dead from the earliest.
\end{abstract}

Keywords: Human skull; Funerary rities; Selection; Conservation; Paleolithic, Mesolithic; Neolithic; Sprinkled; Columbella rustic; Gyraulus; Lithoglypus; Anthropophagy; Fertility; Lake basin; Death; Skeleton; Inhabitants

\section{Introduction}

This article is focused on a reflection on several archaeological evidences related to the treatment of the skull in prehistoric cultures, reporting examples of burials and archaeological sites where cases of manipulation were found for practical and / or ritual purposes. In the cultures of the past, the head was meant as the seat of the soul, which contained the life force, and which possessed extraordinary qualities [1]. It was also the profound symbol of a power closely linked to the concepts of life, death and fertility [2]. Also, after death, the manipulation of the skulls showed that the physical remains of the deceased continued to play an important role in the community life to which he belonged [1]. Funeral customs and customs concerning the preservation of some parts of the deceased, always depend on the religious or animistic concepts of the peoples who practice them. The analysis of the customs related to the conservation of human heads makes it possible to highlight some considerations about the relationships that the various peoples consider existing after death, between the corpse and the spirit that animated it in life [3]. The relationship with life and death that manifests itself in funeral rites already started in the Paleolithic, where the ritual practices performed on individuals were based on the manipulations of the bones of the dead. The human skull was especially important to the point that a true cult developed [4].

There is a rich ethnographic record documenting such practices of manipulation and for many periods of the historic and prehistoric past there is abundant archaeological evidence that testifies the importance attached to the head [5-8]. Interesting is the ethnographic comparison that allows to identify aspects in common, for example, between the Mesolithic communities in various parts of Europe with the populations of the regions of Southwest Asia and North Africa. From Atapuerca in Spain (Homo heidelbergensis) to Bilzingsleben in Germany (Homo heidelbergensis), to Krapina in Croatia (Homo Neanderthal), to Predmosti in the Czech Republic (Homo sapiens) human bones were recurrent elements in the grave goods. In the Russian Palaeolithic Sungir deposit, a female skull was found above the skeleton of a man, while in the tomb of two children an adult femur was found [9]. Since the last phase of the European Upper Paleolithic, many humans remain reveal deliberate traces of human manipulations. Everywhere some bones, especially skulls, have been separated from their respective skeletons to be kept in non-sepulchral contexts and symbolically integrated into the everyday life of the living as relics, connected to ancestral cults or as trophies to be exhibited [10].

The practice of the selection and conservation of human skulls is found quite regularly starting from the last phase of the Upper Paleolithic, the Maddalenian, and then developed during the European Mesolithic (X-VII Millennium). Indeed, in all European cultures of the Upper Paleolithic we have found isolated and sometimes manipulated human remains, the most of them dated between 20000 and 10000 BC. Additionally, in some cases, the skulls are protected with stone circles as in the case of the Rond-du-Barry site (Haute-Loire, France) and perhaps for Abri Pataud (Dordogne, France), while the skull of Rochereil 
(Dordogne, France) has been found on two small limestone slabs, as well as that of Mas D'Azil (Ariége, France) in a niche. Whole or fragmented, the skulls are manipulated and often separated from their skeletons to be integrated into everyday life, perhaps burying them under the houses. This could be pertinent to relatives or relatively important persons in the group, to be kept as a memory and circulated from one place to another [10]. As for the ancient Mesolithic (IX millennium BC), the evidence is not very numerous but still significant. Among others needs to be mentioned the Blatterhohle site (Westfalen, Germany). The analysis of the context suggests that all these elements have been intentionally located in the same place. The hypothesis that they were heads belonged to enemies and preserved perhaps as a memory or warning for rival societies remains valid. Many skulls, in fact, show signs of cut on the external table and at the first cervical vertebrae, all traces compatible with decapitation practices.

In Ofnet (Holheim, Bavaria) cave had been found two contexts of extraordinary importance regarding the selection and preservation of human skulls of all age groups and of both sexes. The pits, not very deep and one meter apart, were located under the entrance of the cavity [11]. Indiscriminately, both adults and children are found (Jeunesse 2012). Moreover, most of the human remains of both pits present traces of violence consisting of signs of cut, scarification and impact traumas on the vertebrae and on the jaws [12]. A rich kit has been found: ochre, coals, some flint tools and pendants, 4500 objects of ornament, including 223 deer canines and 4250 perforated shells of Columbella rustica, Gyraulus, Lithoglypus. In Kanaljorden (Östergötland, Sweden) skull depositions were found on the banks of a former lake basin: some skulls were placed in water while two others underwent a real impalement through wooden supports, still preserved. In both cases, the pole was inserted in length through the foramen magnus towards the cranial vault. The deposit is dated between 6029 and $5640 \mathrm{cal}$ a.C., during the last phase of the Mesolithic [13].

The presence of the small bones of the hands and feet of 12 individuals on the Early Mesolithic site of l'Abri des Autours, Belgium, in conjunction with a few of cranial remains, suggests that at least some complete bodies were originally buried, with the skulls subsequently taken away to be deposited elsewhere [14]. In the Cis-Baikal region in Siberia ( $7500-3700$ cal BP) about 1300 individual burials present and frequent manipulations on the skull of the deceased including the decapitation, the postmortem removal of the skull from the grave and the treatment with fire or the red ochre [15].

Between the third and the beginning of the second millennium $\mathrm{BC}$ the natural cavities were exploited as a place of collective burial, according to a typical custom both in the Apennine and in the Alpine areas. Also, in Italy, funeral practices of manipulation, displacement and removal of the skeleton are attested, revealing a strong symbolism linked to the sacred beliefs and the cult of the ancestors. Recently, a human skull has been found, dated between 3300 and $3600 \mathrm{BC}$, in the Marcel Loubens cave, in the Parco dei Gessi, a few kilometers from Bologna. It is probably a female individual on whom there are tiny traces of manipulation of the corpse such as the severing of tendons, muscles and ligaments [16].

\section{Skull Trepanation and Anthropophagy Practices}

Several ethnographic examples support the analysis of archaeological evidence related to the treatment of skulls in funerary settings. The preservation of the skull as a talisman was also observed at the Dahiachi of Borneo [17] and the Papua of New Guinea [18]. The inhabitants of some areas of Australia use the bones of enemies as amulets [19]. Among the natives of Australia there was the belief that, when you want death of an enemy, you must look for some of his hair and the magician of the tribe practices certain spells [19]. Some people believe that spirits need a free passage to penetrate closed places and get out of them [20]. Concerning the use of cranial drilling in the treatment of mental illnesses or epilepsy, a reference can be found in the idea that the spirit that afflicts it can escape from the hole that the operator practices in the patient's skull.

In human history, cranial trepanation is one of the earliest operations performed in different parts of the world [21,22]. Evidences of cranial trepanation date back to the Upper Paleolithic and Mesolithic periods [23-27] almost to modern times $[28,29]$. On the body of the dead ritualistic trepanations were also performed, to make an amulet or for conservation practices [30]. Post mortem drilling hypotheses from studies on more recent human remains like the skull of Otranto might represent a unique evidence of multiple trepanations carried out to obtain bone powder as ingredient for therapeutic preparations [31]. Several cases of multiple post-mortem trepanations were interpreted as cases of experimental surgery [32].

Also interesting are the archaeological evidences that would testify the practice of anthropophagy for both food and ritual purposes. There are multiple examples from the sites of La Placard (Charente, France), Isturitz (Gironde, France) and Gough's Cave (Somerset, England) [33-35]. A well-known aspect of manipulation of the dead in the Magdalenian involves the preparation of so-called 'skull cups'. These are modified human skulls, and the removal of the facial area and base of skulls was made through repeated blows. In Gough's cave in Somerset, England $(\sim 14,700 \quad B C)$ anthropologists have long studied evidence for cannibalism in the human fossil record [36]. The analysis has identified a higher prevalence and greater range of human chewing modifications than recognized by earlier workers [37]. The human bones belong to four individuals, including a child around three years old and, show abundant evidence of gnawing by humans. It seems that every piece of soft tissue including eyes, ears, cheeks, lips and tongue has been removed with stone tools. In these ritual practices, cannibals preserved the vault of the cranium, separating it from the face: cuts at the base of the skulls and on the cervical vertebrae indicated this took place shortly after death [33]. Objects were 
attached to the skulls using a rope to fix the mandible to the cranium: the skull was probably suspended as confirmed by the drilled perforation at the left parietal of skull [38].

\section{The Modeling of the Skull in Neolithic Contexts}

A 'skull cult' is present as an aspect of the early Neolithic cultures of the Near East. The best-known examples are those from first John Garstang's and then Kathleen Kenyon's excavations at the PPNB (Pre-Pottery Neolithic B) settlement at Jericho (Kenyon 1956). Others have been found at 'Ain Ghazal, Beisamoun, Kfar HaHoresh, Nahal Hemar, Yiftahel, Tell Aswad and Tell Ramad $[39,40]$. The practice continued into the later Neolithic, as seen at Çatalhöyük and Köşk Höyük [41]. Mortuary practices in Near Eastern societies, through people's treatment of corpses after death, provide evidence about thoughts and views of life. The skull was treated in special ways (removed, decapitated, painted, dismembered, plastered, scalped and cached) as an important part of the human body. The skull had a relationship with the life and identity of the dead and created linkage between the living and dead. For the living individual, of course, facial features provide the most immediately accessible means of inter-personal recognition [42]. When combined with skin, hair and eye colour, hair styles and the use of ornamentation the head can become a marker of group affiliation.

In Jericho (also called Tell es-Sultan), near the Jordan River in the West Bank, some 55 kilometres from Jerusalem, the archaeologists have unearthed the remains of more than 20 bodies, the first of which dates back to around 10,000 BC. More than sixty plaster skulls have been found in six sites around the Levant area, usually dated between 7,000 and 6,000 BC, but some date back to $8,000 \mathrm{BC}$. Most of the plastered skulls came from adult males, but some belonged to women and children. The jawbone flesh and bones have been removed from the skulls to model the plaster over the bone and the physical features of the faces seem specific to individuals, suggesting that these decorated skulls were portraits of the deceased and were a form of ancestor worship. The TAC performed in some individuals allowed to detect some masculine connotations (deep palate, robust cheekbones, big mastoid, eyebrows ridge) and feminine ones (lack of nuchal crest, gracile bones) $[43,44]$.

\section{Inside the Cult of the Dead in Italy: The Cemetery of Fontanelle}

In the traditional Neapolitan culture, the rituals of double burial and the cult of the skull have always been important, being the skull a place where the soul traditionally resides. To care for the dead, to take care of their residence, to dialogue with them, to cry and to offer them gifts are ritual operations that establish a relationship and exchange regime perceived as indispensable for the continuation of life and because death had value [45]. The cemetery of Fontanelle in Naples is an ossuary, located in a cave in the tuff hillside in the Materdei section of the city. By the time the Spanish moved into the city in the early 16 th century, there was already concern over where to locate cemeteries outside of the city walls. Many Neapolitans, however, insisted on being interred in their local churches. There are 40000 deposited skulls that constitute a real population of the dead whose identity is not known $[46,47]$. The devotees had the custom to lay the skulls in special wooden cases, identifying them also with a name and a story, which they claimed to be revealed to them in a dream. A precise ceremonial was followed: the skull was cleaned and polished and placed on embroidered handkerchiefs and it was adorned with candles and flowers.

In this regard, the description of the Parthenopean rite of double burial is still interesting, as it is still practiced today: << after the exhumation, the coffin is opened by the workers and it is checked that the bones are completely dry. In this case the skeleton is placed on a special table and the relatives, if they want, elp to free him from the shreds of clothes and possible residues of putrefaction; is washed first with soap and water and then "disinfected" with rags soaked in alcohol that the relatives, "to be sure that cleaning is done carefully", have thought to procure together with the naphthalene with which the body is sprinkled and the sheet that it will be periodically changed and it is the envelope of the body of the dead in its new condition. When the skeleton is clean, it can more easily be treated as a sacred object and can therefore be sent to its new home - which is usually located far from the first burial - with a rite of passage that on a reduced scale reproduces that of the funeral procession that accompanied the dead man to the tomb $[48,49]$.

\section{Conclusion}

It is not always easy to define the symbolism underlying certain behaviors, even if there are numerous anthropological researches dealing with this cultural aspect. This article highlights a very complex ceremony that involved the transition from the community of who is still alive to that of the ancestors accompanying the body of the deceased in the various stages of taphonomic change. The contact with some parts of the body and with the head was an indication of a profound attention to the sacredness of death and of the importance of the body treated in the liminal phase. Taking care of the body could give a sense of continuity of the past through present and future generations. The need to ritualize this delicate "liminal" moment is perceived as more and more emerging in a culture in which death is a taboo. Not only is the funeral, religious or secular, an important ceremonial aspect for mourning. It represents an important phase of transition, of contact and gradual detachment, of the process of mourning, the accompaniment of the body from a temporary burial to a definitive "social" state.

Death is not an instantaneous event that consumes itself in the extinguishing of a sigh but a long and gradual process, a passage from one state of existence to another. For the people of Borneo studied by Hertz [50] the difficult, dangerous passage of the soul of the deceased to the realm of the ancestors had to be accompanied by special care addressed to the corpse: a first placement of the body, inhumed or exposed, was temporary 
[51-54]; this initial funeral ceremony marked the beginning of a liminal phase in which the deceased was no longer alive without yet being completely dead. Practicing the washing of the body, perfuming it, softening its appearance, is not a way to trivialize death; instead it is a ritual that serves to share the pain; it is a way to become aware. It is appropriating the body of your loved one and be able to let it go. To manipulate his head means to recognize his identity even in the post-mortem.

\section{References}

1. Croucher K (2006) Getting Ahead: Exploring meanings of skulls in the Neolithic Near East. In: Bonogofsky M, Skull Collection, Modification and Decoration (edn), British Archaeological Reports International Series S1589, Archaeopress. Oxford, UK, p. 29-44.

2. DeLeonardis L (2000) Th e bodycontext: interpreting Early Nascadecapitated burials. Latin American Antiquity 11(4): 363-386.

3. Pinza G (1898) La conservazione delle teste umane e le idee ed i costumi coi quali si connette. Società geografica italiana. Roma, Italy, 7: 305-492.

4. Ullrich H (2011) Leichenzerstückelung und Schädelkult - abstruse Totenritenin der Menschheitsgeschichte. Bulletin der Schweizerischen Gesellschaft für Anthropologie 17(1-2): 97-104.

5. Schulting RJ (2015) Mesolithic skull cults? In: von Hackwitz K, Peyroteo Stjerna R (Eds.), Ancient Death Ways. Department of Archaeology and Ancient History, Uppsala University, Sweden, Europe, p. 19-46.

6. Armit I (2012) Head Hunting and the Body in Iron Age Europe. Cambridge University Press, Cambridge, USA.

7. Bonogofsky M (2006) Skull Collection, Modification and Decoration. Archaeopress, British Archaeological Reports, Oxford, UK.

8. Hoskins J (1996) Introduction: headhunting as practice and as trope. In: Hoskins J (Eds.), Headhunting and the Social Imagination in Southeast Asia. Stanford University Press, Stanford, USA, p. 1-49.

9. Formicola V (2007) From the Sunghir Children to the Romito Dwarf: Aspects of the Upper Palaeolithic Funerary Landscape. Current Anthropology 48(3): 446-453.

10. Cucchiarini S (2014) Trasformazioni simboliche, dal cadavere alla reliquia: corpi manipolati e resti umani isolatinel Mesolitico europeo. Forma Vrbis, Roma, Italy, p. 2-3.

11. Orschiedt J (1999) Manipulationen an menschli-chen Skelettresten. Taphonomische Prozesse,Sekundärbestattungen oder Kannibalismus? Urgeschichtliche Materialhefte 13, Tübingen, Germany.

12. Jeunesse C (2012) Ofnet et les dépots de tetes dans le Mésolithique du sud-ouest de l'Allemagne, in B.Boulestin e D. Henry-Gambier (sous la direction de), Cranes trophées, cranes d'ancetres de la tete: problémes d'interprétation en archéologie, Actes de la table ronde pluridisciplinaire, musée national de Préhistoire, Les Eyzies-de-Tayac (Dordogne, France), p. 69-75.

13. Hallgren F (2011) Mesolithic Skull Depositions at Kanaljorden, Motala, Sweden. Current Swedish Archaeology 19: 244-246.
14. Cauwe N (1998) La Grotte Margaux à Anseremme-Dinant. Études et Recherches Archéologiques Eraul. University of Liège, Liège, Belgium, p. 59.

15. Weber A, Bazaliiskii V (2016) Spatio-temporal variation in mortuary skull cults among middle Holocene hunter- gatherers of the Baikal region, Siberia. Society for American Archaeology 81st Annual Meeting, Orlando, Finland, Europe.

16. Conti C (2018) Rinvenimento di un cranio umano del IV millennio a.C. nella Grotta Marcel Loubens a San Lazzaro di Savena (BO).

17. Roth H (1896) The Natives of Sarawak and British North Borneo in Journal of Anthropological Institute, London, UK, 21: 117.

18. Windsor G (1853) The native races of the Indian Archipelago: Papuans. Harvard University, London, UK, p. 84.

19. Angas G (1847) Savage life and scenes in Australia and New Zealand, I, University of California Libraries, London, UK, pp. 123.

20. Tylor E (2010) Primitive culture: researches into the development of mythology, philosophy, religion, language, art, and custom. Cambridge University Press, Cambridge, USA.

21. Brothwell D (1972) Digging Up Bones. Trustees of the British Museum, London, UK.

22. Arnott R, Finger S, Smith C (2003) Trepanation: History, Discovery Theory. Swets \& Zeitlinger Publ, Lisse.

23. Ferembach D (1962) La Nécropole Epipaléolithique deTaforalt (Maroc Oriental, Etude de Squeleites Humains). Centre National de la Recheriche Scientific, Rabat, Moracco.

24. Esin U, Harmankaya S (1999) Neolithic in Turkey the Cradle of Civilization. In: Ozdogan M, Basgelen N(Eds.), Arkeoloji ve Sanat Yayınları, Istanbul: pp. 115-132.

25. Hochman II (1966) The Population of Ukraine in the Mesolithic and Neolithic. Science, Moscow, Russia.

26. Capasso L, Di Tota G (1996) Possible therapy for headachesin ancient times. International Journal of Osteoarchaeology 6: 316-319.

27. Mednikova MB, Dobrovolskaya CF, Buzhilova AP, Khartanovich VI, Seleznev VI, Moiseev VG, Potrahov NN (2012) Once again, the issue of early trepanation head in the Stone Age: Telmanovskiy site and its possible interpretation. KSIA (Brief Communications of the Institute of Archaeology) Moscow, 227: 111-121.

28. Meschig R (1983) Zur Geschichte der Trepanation, unter besonderer Berucksichtigung der Schadeloperationen beiden Kisii im Hochland Westkenian. Dusseldorfer Arbeiten zur Geschichte der Medizin p. 57.

29. Margetts EL (1967) Trepanation of the skull by the medicine-men of primitive culture with reference to present day native East African practice. Disease in Antiquity, DR Brothwell, AT Sandison (eds.). Thomas Book, Illinois, pp. 673-701

30. Slepchenko SM, Vybornov AV, Slavinsky VS, Tsybankov AA, Matveev EE (2016) Ante Mortem Cranial Trepanation in the Late Bronze Age in Western Siberia. International Journal of Osteoarchaeology 27(3): 356-364. 
31. Giuffra V, Fornaciari G (2015) Pulverized human skull in pharmacological preparations: Possible evidence from the martyrs of Otranto Journal of Ethnopharmacology 160(3): 133-139.

32. Campillo D (1993) Paleopatologia: Los Primeros Vestigios de la Enfermedad. Fundacion Uriach, Barcelona, Spain, Europe.

33. Bello SM, Parfitt, SA, Stringer CB (2011) Earliest Directly Dated SkullCups. plosone 6(2): e17026.

34. Breuil Abbe H, Obermaier H (1909) Cranes Paleolithiques Faconnes En Coupes. L'Anthropologie 20: 523-530.

35. Buisson D, Gambier D (1991) Façonnage et gravures sur des os humains d'Isturitz (Pyrénées-Atlantiques). Bulletin de la Société préhistorique française 88(6): 172-177.

36. Bello SM, Saladié P, Cáceres I, Rodríguez-Hidalgo A, Parfitt SA (2015) Upper Palaeolithic ritualistic cannibalism at Gough's Cave (Somerset, UK): The human remains from head to toe. J Hum Evol 82: 185-186.

37. Fernandez-Jalvo Y, Andrews P (2011) When Humans Chew Bones. Journal of Human Evolution 60(1): 117-123.

38. Gresky J, Haelm J, Clare L (2017) Modified human crania from Göbekli Tepe provide evidence for a new form of Neolithic skull cult Sci Adv 3(6): e1700564.

39. Arensburg B, Hershkovitz I (1989) Artificial skull treatment in the PPNB period: Nahal Hemar. In: Hershkovitz I (Eds.), People and Culture in Change: Pro-ceedings of the Second Symposium of Upper Paleolithic, Mesolithic, and Neolithic Populations of Europe and the Mediterranean Basin. Oxford: Archaeopress, British Archaeological Reports, pp. 115-131.

40. Milevski I, Khalaily H, Getzov N, Hershkovitz I (2008) The plastered skulls and other PPNB finds from Yiftahel, Lower Galilee (Israel). Paléorient 34: 37-46.

41. Croucher K (2012) Death and Dying in the Neolithic Near East. Oxford University Press, Oxford, UK.

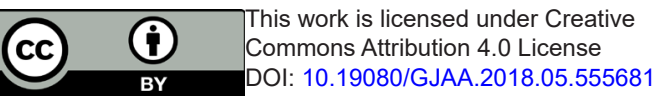

42. Young AW, Bruce V (2011) Understanding person perception. British Journal of Psychology 102(4): 959-974.

43. Fletcher A (2015) From Person to Ancestor, the plastered skull from Jericho, Italy.

44. Fletcher A, Pearson J, Ambers J (2008) The manipulation of social and physical identities in the Neolithic: a new radiographic investigation of a plastered skull from Jericho. Cambridge Archaeological Journal 18: 302-325.

45. Faeta F, Malabotti M (1980) Imago mortis: simboli e rituali della morte nella cultura popolare dell'Italia meridionale. De Luca, Roma, Italy.

46. Erao M (2012) Il ventre di Napoli. BUR, Milano, Italy.

47. Varriale R (2009) Undergrounds in Naples. I sottosuoli napoletani. In: Ricerche di Economia e Storia, Roma, Italy, pp. 91-103.

48. Pezzini F (2006) Death rituals: the southern Italy secondary burials in modern age. Medicina nei secoli, 18(3): 897-924.

49. Corso R (1936) Nuova interpretazione del rito della posizione rannicchiata. Soc. italiana per il progresso delle scienze, 14: 3.

50. Hertz R (1907) Contribution a une etude sur la representation collective de la mort. Annee Sociologique 10: 48-137.

51. Fernández Jalvo Y, Andrews P (2011) When humans chew bones. Journal of Human Evolution 60(1): 117-123.

52. Kenyon KM (1956) Jericho and its setting in Near Eastern history. Antiquity 30: Cambridge university press, USA, pp. 184-197.

53. Nello S (2014) Apprivoiser la mort: ritualità, sacralità e memoria nelle opere di Sophie Zénon. Tesi di Laurea Magistrale, Università degli Studi di Pisa, Europe.

54. Orschiedt J, Gehlen B, Schön W, Gröning F (2012) The Neolithic and Mesolithic cave site Blatterhohle. In: Westphalia. Notae Prehistoricae 32: 73-88.

\section{Your next submission with Juniper Publishers will reach you the below assets}

- Quality Editorial service

- Swift Peer Review

- Reprints availability

- E-prints Service

- Manuscript Podcast for convenient understanding

- Global attainment for your research

- Manuscript accessibility in different formats

( Pdf, E-pub, Full Text, Audio)

- Unceasing customer service

Track the below URL for one-step submission https://juniperpublishers.com/online-submission.php 